\title{
INCREASED READING SKILLS ALOUD USING MODELING STRATEGIES IN GRADE II STUDENTS OF SDN 009 SANGATA UTARA
}

\author{
Elsy Syahdinar, Ahmad Ridhani, Surya Sili \\ Elsysyahdinarr06@gmail.com
}

\begin{abstract}
The purpose of this research is ti find out the results of the use of modeling grade in SDN 009 Northen Sangatta. Specially for the improvement of reading aloud in the pre reading stage when reading the post reading stage with the modelling strategies of of second grade elementary school student 009 Northen Sangatta. This research methodology is a type of classroom action research, research procedures used are planning, action, observation, and reflection. This research uses three cycles one cycle twice meeting. The problems contained in the first cycle will be followed up by the second cycle research and the third cycle research.The results of this study are the ability of pre reading in the first cycle an average of $60,7 \%$, the twice cycle an average of $73,2 \%$ and an average the third cycle of $81,8 \%$. The ability to read aloud from the pre cycle test value which is used as the basic value obtained before the average action of 64,4 with sufficiently improved criteria in the first cycle of action of an average of 67,5 with sufficient criteria, increased cycle two by an average of 69,8 with the criteria are sufficient and increase in the average three cycle of 75,4 with good criteria. Post reading ability in cycle one is $64,2 \%$ an average cycle two is $69,8 \%$ and cycle three is $81,8 \%$. The conclusion that the application of modeling strategies can increase the ability to read aloud preweens when reading and post reading of second grade elementary school student 009 Northen Sangatta.
\end{abstract}

Keywords : Loud Reading Skills, Modeling Stratetegy

\section{INTRODUCTION}

Reading is one of the activities carried out by students because they know the school. However, when improving the reading skills of students at this time is still low. This is of course very alarming considering the role of reading is very important in the learning process. Reading fondness is still lacking these days, this problem can be seen from students' laziness in learning. The ability to read is the main capital of students in obtaining quality education and knowledge. Without this provision, we will not obtain information and knowledge. The main purpose of reading is to get information and read the meaning of reading. If reading skills increase, the main goal in learning will be easily obtained. Reading activities in the teaching and learning process in class while discussing several factors, including: factors teacher, student, media, method, and venue for teaching and learning interactions.

However, the data of learning outcomes read aloud to students in grade II SDN 009 North Sangata, amounting to 29 students on student pre-cycle learning outcomes. criteria for learning outcomes of less than 14 students or $48.3 \%$ of the total number of students with an average of 60 learning outcomes with less criteria still below the standard of mastery learning. The low ability to read aloud students of grade II at SD
Negeri 009 Sangata Utara is the ability of students to be seen in aspects of intonation, pronunciation, pauses in fluency and even many errors in punctuation that students pronounce. Students are poorly trained in reading aloud so that many punctuation marks have not been able to distinguish. This happened

students are less interested in following reading lessons because the methods used by the teacher are still conventional or one-way. The teacher only conveys the understanding and techniques of reading aloud without giving examples of how to read well and correctly with aspects such as pronunciation, intonation, pauses and tempo that should be considered in reading aloud.

Modeling strategy is a learning technique using models or teaching aids. The presence of teaching aids will create an atmosphere of teaching and learning activities more interesting and exciting and students can play an active role in learning. Increasing the ability to read aloud through modeling strategies in class II students at SDN 009 Sangata Utara is expected to overcome the difficulties of students in learning the ability to read aloud. Modeling strategy as a component has an important role in learning to carry out learning. Giving activities models in learning aim to express ideas that we think about by demonstrating, so 
students learn or do something that means there are models that are imitated and observed by students because the models presented are related to carrying out loud reading. The presence of models by involving the teacher provides a motivation and activeness of students in learning. Applying the modeling strategy, the trainer or teacher will demonstrate or give an example of how to do a skill, while the students who are trained will observe and imitate the reading ability of the teacher aloud.

1. Identification of Problems

The identification of the problem based on the background of the problem is as follows.

a. The ability to read aloud students an average of 60 with sufficient criteria has not yet reached the completeness of the learning outcomes of an average of $70 \mathrm{KKM}$ that have been set. Grade II students of SDN 009 North Sangata consisting of 20 students, has not yet reached its completeness. There are 1 students with criteria of less or about $5 \%$ of the total number of students and there are 19 students with sufficient criteria or as much as $95 \%$ of the total number of students.

b. The ability of students in the reading aspect evaluation aloud such as aspects of fluency in reading, intonation of the correct words or sentences, accuracy in pronunciation and loudness of the voice is not optimal

c. The learning model used does not provide student activity for learning

d. Teachers do not encourage students to understand what they are reading, that is understanding obtained from the essence or the main contents that are found in a book or text

e. Teachers lack motivation in learning that is fun for students

2. Limitation of Problems

Based on the background and identification of the problem above, the researcher provides the following limitations.

a. The improvement that is adopted in this research is the ability to read aloud in Indonesian subjects

b. Increased student activity in learning to read aloud in pre-reading, when reading and post-reading c. he ability to read aloud with modeling strategies of Class II students of SDN 009 North Sangata

d. Reading reading aloud aspects such as fluency in reading, correct intonation of words or sentences, accuracy in pronunciation and loudness of voice.

3. Formulation of Research Problems

Problems that can be formulated in this study are "

a. How to improve reading aloud at the stage of reading with strategy modeling of Class II students of SDN 009 North Sangata? "

b. How to improve reading aloud at the time of reading with modeling strategies of Grade II students of SDN 009 North Sangata? "

c. How to improve reading aloud in the post stage with the modeling strategies of Grade II students of SDN 009 North Sangata?"

4. Research Objectives

Based on the formulation of the problem the objectives of classroom action research are as follows.

a. Generally

Knowing the results of the use of modeling strategies to improve the ability to read aloud with modeling strategies of second grade students of SDN 009 North Sangata

b. In particular

1) To increase the reading aloud in the pre-reading stage with modeling strategies of grade II students of SDN 009 North Sangata "

2) To increase reading aloud in stageswhile reading with modeling strategies of second grade students at SDN 009 North Sangata "

3) To improve reading aloud in the postreading stage with modeling strategies of Grade II students of SDN 009 North Sangata "

5. Research Benefits

The results of this determination contribute to efforts to improve the quality of education. As for the detailed benefits include.

a. Theoretical benefits

From a scientific point of view, this research is expected to be able to increase the repertoire of knowledge about increasing activity and the ability to read aloud with the modeling 
strategies of class II students of SDN 009 North Sangata

b. Perpetual benefits

1) For teachers

Increase teacher creativity in teaching Indonesian so that learning is not verbalism. The teacher can find out the variety of learning that can be used as an effort to improve students' intensive reading skills and in accordance with the methods used.

2) For students:

Improving students 'ability to read aloud through developing students' creativity in the learning process and providing motivation for students to actively read.

3) For schools:

As input in efforts to improve and enhance learning so that it can support the achievement of curriculum and power targets

\section{LITERATURE REVIEW}

1. Reading

Henry Guntur Tarigan (2008: 7) revealed that reading is a process carried out to obtain a message, which the writer wants to convey through the media of words / written language. The same thing was also stated by Harjasujana in Khuddaru Sadhono (2012: 65) which states that reading is an activity responding to written symbols using appropriate understanding.

Samsu Somadayo (2011: 4) defines reading as an interactive activity to pick and understand the meaning or meaning contained in the written material. Meanwhile Klein, et al (Farida Rahim 2008: 3) suggest the definition of reading includes (1) reading is a process, (2) reading is strategic, and (3) reading is interactive.

2. Reading aloud

The reading process can be grouped into several types. According to Henry Guntur Tarigan (2008: 23), in terms of whether or not the sound of the reader when he reads, the reading process can be divided into: a) reading aloud, reading aloud, and reading oral (reading out loud, oral reading, reading aloud), and b) silent reading.

Kridalaksana in Haryadi and Zamzani, (1996: 32) stated that "reading is the skill to recognize and understand writing in the form of sequences of graphic symbols and the change into meaningful speech in the form of tacit understanding or loud utterance". The form of quiet understanding here means to read silently, while the form of utterance aloud means the reading aloud. According to Supriyadi (1992: 115), "in Elementary Schools the type of reading by filtering or voicing what is read is mostly or even fully done in grades II and II. For higher class grades, the frequency of technical reading activities is increasingly reduced".

Sabarti Akhadiah, et al (1991: 11) also explain the differences in teaching reading in low and high classes. Reading lessons in higher classes prioritize aspects of understanding. The teaching of beginning reading is more emphasized on developing basic reading skills. Students are required to be able to voice sentences that are presented in written form. In this case, also included aspects of fluency reading. Students must be able to read discourse fluently, not just read words or recognize written letters.

Reading aloud is an activity or activity that is a tool for teachers, students, or readers together with other people or listeners to capture and understand information, thoughts and feelings of a person "(Henry Guntur Tarigan, 2008: 23). In reading aloud, the reading process is done by voicing the written symbols on the reading. Compassion K. Suyanto (2007: 64) explains that "reading aloud (reading aloud) is intended to train so students can read with pronunciation or correct speech".

3. Strategy Modeling

Contextual learning or Contextual Teaching Learning (CTL) is a concept that helps teachers link material taught with real-world situations and encourages students to make connections between their knowledge and its application in their lives as family and community members.

Contextual learning or Contextual Teaching Learning (CTL) is a concept that helps teachers link material taught with real-world situations and encourages students to make connections between the knowledge they have and their application in their lives as family and community members. According to Suprijono, Agus, there are 7 components in CTL namely

a. Constructivism (Contructivism) namely that knowledge is built by humans little 
by little whose results are expanded through limited contexts.

b. Finding (Inquiry) is that the knowledge, skills and other abilities needed are not the result of remembering a set of facts but the result of finding oneself.

c Asking (Questioning) is learning that is built through interactive dialogue or question and answer by all elements involved in the learning community.

d. Learning Community (Learning Community) is learning that accustoms students to collaborate and utilizing learning resources from his friends.

e. Modeling is learning that demonstrates something learners learn by focusing procedural knowledge so that students can imitate what is done by the model.

f. Reflection (Reflection) is a way of thinking about what has just happened or has just been learned.

g. Authentic Assessment is an effort to collect various data that can give an overview of students' learning development.

From some of the CTL components above, the researcher uses one of the components, namely Modeling because the learning process of implementing reading aloud needs to provide examples so that students can imitate the model. Modeling is a principle that is quite important in learning CTL because through Modeling students can avoid abstract theoretical learning that can enable verbalism. (Sanjaya 2007: 266)

The modeling steps according to Bandura in Heri Rah Yubi, (2012: 106-108) are as follows:

a. Attention Process (Attention Processes)

The process of attention is when someone pays attention to an event or behavior. This attention is influenced by the observer's association with his model, the nature of the attractive model and the significance of the observed behavior for the observer. For example the teacher or model gives examples of certain activities (demonstrations) in front of students in accordance with the scenario that has been prepared. Students make observations on the teacher's skills (models) in carrying out these activities using the observation sheets that have been provided. Teachers and students discuss the results of observations made. The purpose of this discussion is to look for shortcomings and difficulties of students in observing the steps of the activity delivered by the teacher and to train students in using observation sheets.

b. Retention Process (Warning Process / Retention Process)

The process of warning (retention) is the ability to remember when someone has paid attention to a model and its behavior. For example the teacher explains the structure of the steps of the activity (demonstration) that has been observed by students. This is done to emphasize certain steps that are considered important based on what has been presented.

c. Motoric Reproduction Processes

The process of motor reproduction is an activity that mimics what has been stored in the brain. For example, students are assigned to prepare steps for their own activities in accordance with the steps that have been exemplified. Furthermore, the results of the activities are presented in the form of performance that will provide reflection when the performance is carried out in turns.

d. Reinforcement and Motivational Processes

Learning through observation becomes effective if the learner has a high motivation to listen to the behavior of the model. For example, during a performance, other students are given the opportunity to present their observations. As a form of appreciation, in the form of awards from colleagues.

e. Representation Processes

The behavior to be imitated must be symbolic in reminding. Both in verbal form and in form image / imagination. In the verbal form to verbally evaluate the observed behavior, and determine which ones are discarded and attempted to do while in the form of imagination to symbolically train what is thought without doing it physically.

f. Behavior Production Processes After watching intently and putting it into memory, people will behave. Changing from a picture of the mind to behavior that raises the need for evaluation. 


\section{RESEARCH METHOD}

1. Type of Research

This type of research is a type of classroom action research. According to Kusumah and Witagama (2012: 9) Classroom Action Research is research conducted by teachers in their own classrooms by (1) planning, (2) implementing, and (3) reflecting collaborative and participative actions with the aim of improving their performance as teachers, so that student learning outcomes can improve. According Suharsimi Arikunto, et al, (2016: 42) there are four important stages in Classroom Action Research (CAR), namely: planning, implementing actions, observing and reflecting

2. Time and Place of Research

The location or place of the author conducting this research is SDN 009 North Sangata. This research was conducted in class II students with a total of 29 students. Classroom action research on learning Indonesian in loud reading was conducted in the 2017/2018 school year.

3. Research Subjects and Subjects

The subject of this classroom action research was the second grade students of SDN 009 North Sangata, whose research plan was carried out in two cycles, in each cycle two meetings. The object of this study is a modeling strategy to improve the ability to read aloud.

\section{RESEARCH RESULTS AND DISCUSSION \\ 1. Research results}

The study was conducted on grade II students at SDN 009 Sangata Utara. The low ability to read aloud to students on the ability of students can be seen in aspects of intonation, pronunciation, pauses in fluency and even many errors in punctuation that students pronounce. Students are poorly trained in reading aloud so that many punctuation marks have not been able to distinguish.

\section{a. Prasiklus}

The prasiklus action as the ability to read aloud serves to find out the increase in the ability to read aloud as a comparison after conducting research, the results of prasilklus learning are also used to determine the improvement in learning outcomes in cycle I and cycle II. The ability to speak Indonesian prasiklus in Indicators aspects of the assessment of the ability to read aloud is an average pronunciation of 57.2 intonation of an average of 57.1 pauses of an average of 57.6 and an average tempo of 57.9 with an average overall of 57.4 with less criteria.

b. Cycle I

The students' pre-reading skills were $60.7 \%$. The ability to read aloud in cycle I in the aspect of fluency in reading an average of 68.5 intonations of correct words or sentences averaged 66.8 accuracy in the pronunciation of the average of 66.6 and an average loudness of 67.9 with an overall average of 67.5 with sufficient criteria. The average student reading ability is $64.2 \%$

c. Cycle II

Students' reading ability Average score of $73.2 \%$. The ability to read aloud in cycle II in the aspect of fluency in reading an average of 71.1 intonation of the correct word or sentence is an average of 69 accuracy in an average pronunciation of 69.1 and loudness of an average of 70.1 with an overall average of 69.8 with sufficient criteria. Students' post-reading ability with an average score of $72.3 \%$

d. Cycle III

The reading ability of students on average is $81.8 \%$. The ability to read aloud in the first cycle in the aspect of fluency in reading an average of 76.6 intonation of the correct word or sentence is an average of 75 accuracy in an average pronunciation of 74.4 and an average loudness of 75.4 with an average overall averaging 75.4 with good criteria. Post-reading ability of students with an average of $81.8 \%$

2. Discussion

a. Cycle I

The teacher's activity in conveying lessons in reading aloud with pronunciation, intonation, pauses and tempo correctly and clearly and gives students the opportunity to ask questions on the subject matter. Determination of loud reading according to the modeling strategy used. The teacher in giving guidance to students in demonstrating reading aloud is considered good. Student activities in reading aloud to aspects of reading aloud such as pronunciations, intonations, pauses and tempos have been assessed as 
good but need to be improved at the next meeting. The learning process shows that students' attention in understanding the learning objectives, taking notes listening to the teacher's explanation, and paying attention to the teacher's explanation and asking if it is unclear is considered good. Students are motivated to learn because the delivery of subject matter in accordance with the learning methods used and the instructor is able to attract students' interest to learn.

b. Cycle II

The teacher's activities in conveying lessons in reading aloud with pronunciation, intonation, pausing and tempo correctly and clearly and giving students the opportunity to ask questions on the study of reading aloud. Determination of loud reading according to the modeling strategy used. Teacher in providing guidance to students in demonstrating reading aloud is very good. The use of time in learning is effective and efficient.

Student activities in reading aloud to aspects of reading aloud such as pronunciations, intonation, pauses and tempo have been assessed as good. The learning process shows that students' attention in understanding the learning objectives, taking notes listening to the teacher's explanation, and paying attention to the teacher's explanation and asking if it is not clear reading aloud in the reading text is considered good. Students are motivated to learn because the delivery of subject matter in accordance with the learning methods used and the instructor is able to attract students' interest to learn. Student participation in giving opinions in the discussion, engaging in question and answer interactions and making conclusions are considered good. The modeling strategy, the process of student acceptance of the lesson will be more memorable in depth, so as to form understanding properly and perfectly.

c. Cycle III
The teacher's activity in conveying lessons in reading aloud with pronunciation, intonation, pauses and tempo correctly and clearly and gives students the opportunity to ask questions on the subject matter. Determination of loud reading according to the modeling strategy used. The teacher in providing student guidance in providing examples of reading aloud is not yet optimal.

Student activities in reading aloud to aspects of reading aloud such as pronunciations, intonation, pauses and tempo have been assessed as good. The learning process shows that students' attention in understanding the learning objectives, taking notes listening to the teacher's explanation, and paying attention to the teacher's explanation and asking if it is less clear is evenly distributed throughout student. Student participation in giving opinions in the discussion, engaging in question and answer interactions is considered good

\section{CLOSING}

\section{Conclusions}

Based on the results of research conducted by the author, it can be concluded that the application of modeling strategies can improve the ability to read aloud the second grade students of SDN 009 North Sangata, namely as follows.

a. The results of this study were the ability of preliminary reading of cycle 1 research by an average of $60.7 \%$ of the second cycle research by an average of $73.2 \%$ and the third cycle research by an average of $81.8 \%$.

b. The ability to read aloud from the test prasiklus value of an average of 64.4 with the criteria quite increased in the first cycle of research an average of 67.5 with sufficient criteria, increased in the second cycle of research by an average of 69.8 with sufficient criteria and increased cycle III research by an average of 75.4 with good criteria.

c. Ability to read in cycle 1 research on average $64.2 \%$ cycle II research on average $69.8 \%$ and cycle II research on average $81.8 \%$

2. Suggestions 
Suggestions that the author can give based on the results of the study are as follows.

a. For teachers to increase the creativity of teachers in reading aloud so that learning is not verbalism and can find out variations in learning that can be used to improve students' reading skills aloud.

b. Students are expected to improve reading aloud by fulfilling aspects of reading aloud such as pronunciation, intonation, pauses and tempo and optimizing the ability to think positively in developing themselves in achieving optimal learning success.

c. For schools as input in efforts to improve and improve Indonesian language learning so that it can support the achievement of curriculum targets and student absorption as expected and help develop practical knowledge in the world of education.

\section{DAFTAR PUSTAKA}

Abdullah, Ridwan 2013. Inovasi Pembelajaran, Jakarta: Bumi Aksara.

Arikunto, Suharsimi. 2013a. Dasar-dasar Evaluasi Pendidikan. Jakarta: Rineka Cipta

Arikunto, Suharsimi. 2008. Penelitian Tindakan Kelas Jakarta: Bumi Aksara.

Benny A Pribadi. 2010 Media Pembelajaran Jakarta : Raja Grafindo Persada.

Dahar, Ratna Wilis. 1996. Teori-Teori Belajar. Bandung: Erlangga

Darsono, dkk. 2000. Belajar dan Pembelajaran. Semarang: IKIP Semarang Press.

Daradjat Zakiah,1995 Metodik Khusus Pengajaran Agama Islam. Jakarta: Bumi Aksara.

Depdiknas. 2002. Penelitian Berbasis Kelas. Jakarta: Direktorat Pendidikan Lanjutan Pertama.

Djamrah, Syaiful Bahri 2014, Strategi Belajar Mengajar. Jakarta: Rineka Cipta.. 91
Fudyartanto. 2002. Psikologi Pendidikan dengan Pendekatan Baru. Yogyakarta: Global Pustaka Utama.

Hamalik, Oemar. 2003. Proses Belajar Mengajar, Jakarta: Bumi Aksara.

Hamalik, Oemar. 1990. Perencanaan Pengajaran Berdasarkan Pendekatan Sistem. Bandung: Citra Aditya.

Haryadi dan Zamzani. 1996. Peningkatan Keterampilan Berbahasa Indonesia. Jakarta: Depdikbud.

Iskandarwassid dan Dadang Sunendar. 2013. Strategi Pembelajaran Bahasa. Bandung: PT Remaja Rosda karya.

Kasihani K.E. Suyanto. 2007. English for Young Learners: Melejitkan $P_{1}$ Anak Melalui English Class yang \& ur, Asyik, dan Menarik. Jakata: Bumi Aksara.

Mudjiono, Dimyanti. 2002. Belajar Dan Pembelajaran: Jakarta Rineka Cipta.

Mujiyanto, Yant dkk. 2000. Puspa Ragam Bahasa Indonesia. Surakarta: UNS Press

Ngalim Purwanto. 1990. Psikologi Pendidikan. Bandung: Remaja Rosdakarya.

Nurhadi dan Agus Gerrad Senduk. 2003. Kontekstual dan Penerapannya dalamKBK. Malang: Universitas Negeri Malang.

Olivia Femi. 2008. Tools for Study Skills Teknik Membaca Efektif: Menciptakan Kebiasaan Belajar yang Efektif dengan Membaca Kritis dan Formula 5S. Jakarta: Elex Media Komputindo.

Rahim 2009, Pengajaran Membaca di Sekolah Dasar, Jakarta: Bumi Aksara

Rahim, Farida 2011. Pengajaran Membaca di Sekolah Dasar. Jakarta: Bumi Aksara 
Sabarti, Akhadiah, dkk. 1991. Bahasa Indonesia II. Jakarta: Depdikbud

Sadhono, Khuddaru dan St. Y. Slamet. 2012. Meningkatkan Keterampilan erbahasa Indonesia (teori dan Aplikasi). Bandung: Karya Putra Darwati.

Somadayo, Samsu 2011. Strategi dan Teknik Pembelajaran Membaca. Yogyakarta: GrahaIlmu.

Sanjaya, Wina 2006. Strategi Pembelajaran Jakarta : Prenada Media.

Sardiman, A. M. 2001. Interaksi dan Motivasi Belajar Mengajar. Jakarta: Rajagrasindo Persada.

Supriyadi. 1992. Materi Pokok Pendidikan Bahasa Indonesia 2. Jakarta: Depdikbud.

Tarigan, Henry Guntur 2008. Membaca Sebagai Suatu Keterampilan Berbahasa. Bandung: Angkasa.

Trianto2011. Model Pembelajaran Terpadu. Jakarta: Bumi Aksara

Pribadi, Benny 2010 Media Pembelajaran Jakarta : Raja Grafindo Persada.

Winataputra. 2007. Strategi Belajar Mengajar. Jakarta: Universitas Terbuka.

Zuchdi, Darmiyati 2007. Strategi Meningkatkan Kemampuan Membaca:Peningkatan Komprehensi. Yogyakarta: UNY Press

Zuchdi, Darmiyati dan Budiasih. 1996. Pendidikan Bahasa dan Sastra Indonesia di Kelas Rendah. Jakarta: Depdikbud. 